\title{
Atmospheric oxidation in the Mexico City Metropolitan Area (MCMA) during April 2003
}

\author{
T. R. Shirley ${ }^{1}$, W. H. Brune ${ }^{1}$, X. Ren ${ }^{1}$, J. Mao ${ }^{1}$, R. Lesher ${ }^{1}$, B. Cardenas ${ }^{2}$, R. Volkamer ${ }^{3}$, L. T. Molina ${ }^{3}$, M. J. Molina ${ }^{3}$, \\ B. Lamb ${ }^{4}$, E. Velasco ${ }^{4}$, T. Jobson ${ }^{5}$, and M. Alexander ${ }^{5}$ \\ ${ }^{1}$ Pennsylvania State University, University Park, PA, USA \\ ${ }^{2}$ Autonomous Metropolitan University, Mexico City, Mexico \\ ${ }^{3}$ Massachusetts Institute of Technology, Cambridge, MA, USA \\ ${ }^{4}$ Washington State University, Pullman, WA, USA \\ ${ }^{5}$ Pacific Northwest National Laboratory, Richland, WA, USA
}

Received: 1 July 2005 - Published in Atmos. Chem. Phys. Discuss.: 17 August 2005

Revised: 20 April 2006 - Accepted: 9 June 2006 - Published: 7 July 2006

\begin{abstract}
The Mexico City Metropolitan Area (MCMA) study in April 2003 had measurements of many atmospheric constituents, including $\mathrm{OH}$ and $\mathrm{HO}_{2}$. It provided the first opportunity to examine atmospheric oxidation in a megacity in a developing country that has more pollution than typical U.S. and European cities. At midday, $\mathrm{OH}$ typically reached $0.35 \mathrm{pptv}\left(\sim 7 \times 10^{6} \mathrm{~cm}^{-3}\right)$, comparable to amounts observed in U.S. cities, but $\mathrm{HO}_{2}$ reached 40 pptv, more than observed in most U.S. cities. The $\mathrm{OH}$ reactivity was also measured, even during the highly polluted morning rush hour. MCMA's $\mathrm{OH}$ reactivity was $25 \mathrm{~s}^{-1}$ during most of the day and $120 \mathrm{~s}^{-1}$ at morning rush hour, which was several times greater than has been measured in any U.S. city. Median measured and modeled $\mathrm{OH}$ and $\mathrm{HO}_{2}$ agreed to within combined uncertainties, although for $\mathrm{OH}$, the model exceeded the measurement by more than $30 \%$ during midday. OH production and loss, which were calculated from measurements, were in balance to within uncertainties, although production exceeded loss during morning rush hour. This imbalance has been observed in other cities. The $\mathrm{HO}_{2} / \mathrm{OH}$ ratio from measurements and steady-state analyses have essentially the same dependence on NO, except when NO was near 100 ppbv. This agreement is unlike other urban studies, in which $\mathrm{HO}_{2} / \mathrm{OH}$ ratio decreased much less than expected as NO increased. As a result of the active photochemistry in MCMA 2003, the median calculated ozone production from measured $\mathrm{HO}_{2}$ reached $50 \mathrm{ppbh}^{-1}$, a much higher rate than observed in U.S. cities.
\end{abstract}

Correspondence to: W. H. Brune

(brune@ems.psu.edu)

\section{Introduction}

Megacities contain not only millions of people but also elevated levels of airborne pollutants. These pollutants are generated by the transportation and industry necessary to support these millions. The fast chemistry that transforms primary pollutant emissions of nitrogen oxides $\left(\mathrm{NO}_{\mathrm{x}}\right)$ and volatile organic compounds (VOCs) is initiated by reactions of the hydroxyl radical, $\mathrm{OH}$, with VOCs. The subsequent reactions produce the hydroperoxyl radical, $\mathrm{HO}_{2}$, which reacts with $\mathrm{NO}$ to reform $\mathrm{OH}$ and create $\mathrm{NO}_{2}$, resulting in the production of the pollutant ozone $\left(\mathrm{O}_{3}\right)$. Low volatility VOCs are also generated, resulting in the formation of secondary organic aerosol mass. Together, $\mathrm{OH}$ and $\mathrm{HO}_{2}$, called $\mathrm{HO}_{\mathrm{x}}$, form a rapid reaction cycle that drives this atmospheric chemistry.

Several field studies that include $\mathrm{HO}_{\mathrm{x}}$ measurements have been conducted in urban environments in the United States, including Los Angeles, California (George et al., 1999), Nashville, Tennessee (Martinez et al., 2003), Houston, Texas (Martinez et al., 2002) and New York City, New York (Ren et al., 2003a). Field studies with $\mathrm{HO}_{\mathrm{x}}$ measurements have also been conducted in urban air in Europe as well, including Berlin, Germany (Volz-Thomas et al., 2003, and accompanying papers) and Birmingham, United Kingdom (Heard et al., 2004; Emmerson et al., 2005). The Mexico City Metropolitan Area (MCMA), a megacity, has more pollution than any of these other urban environments (Molina and Molina, 2002).

A useful addition to the typical measurement suite for studying atmospheric oxidation is the measurement of $\mathrm{OH}$ reactivity, the inverse of the $\mathrm{OH}$ lifetime (Kovacs and Brune, 2001; Kovacs et al., 2003). This manuscript describes a method for obtaining $\mathrm{OH}$ reactivity measurements even in

Published by Copernicus GmbH on behalf of the European Geosciences Union. 
the presence of high levels of nitrogen oxides $\left(\mathrm{NO}_{\mathrm{x}}\right)$. The $\mathrm{OH}$ reactivity measurement is particularly useful in two ways. First, by comparing the measured $\mathrm{OH}$ reactivity with the calculated $\mathrm{OH}$ reactivity, which is the sum of the product of $\mathrm{OH}$ reactants and their reaction rate coefficients, the completeness of the measured reactants can be tested (Kovacs et al., 2003; DiCarlo et al., 2004). Second, some properties of atmospheric oxidation chemistry can be tested independently of detailed model oxidation mechanisms. For instance we can test the expected balance between $\mathrm{OH}$ production and loss and the dependence of the $\mathrm{HO}_{2} / \mathrm{OH}$ ratio on controlling variables such as nitric oxide (NO). We have also shown that in some regions $\mathrm{OH}$ reactivity combined with a general knowledge of the VOC speciation is sufficient to model the observed $\mathrm{OH}$ and $\mathrm{HO}_{2}$ with a fidelity that is as good as is obtained in field studies with more frequent measurements of speciated VOCs (Ren et al., 2005, 2006).

$\mathrm{OH}, \mathrm{HO}_{2}, \mathrm{OH}$ reactivity, and other atmospheric constituents important for studying atmospheric oxidation were measured during the Mexico City Metropolitan Area 2003 (MCMA-2003) study, which was held in the MCMA during April 2003. MCMA is at a high altitude $(\sim 2240 \mathrm{~m})$ near the equator at $19^{\circ} 25^{\prime} \mathrm{N}$ latitude. At this high altitude and low latitude, intense solar radiation penetrates to the surface causing active photochemistry. In addition to the radiation, the area's orography, with mountains to the west, east, and south of the metropolitan area, traps pollutants in the basin. As a result, MCMA experiences high pollution levels. This study was an opportunity to develop a better understanding of MCMA's high pollution levels of ozone and secondary particulate matter. It also stretches the envelope of polluted environments that have been studied with a measurement suite that includes measurements of $\mathrm{OH}$ and $\mathrm{HO}_{2}$.

\section{Description of the MCMA 2003 study}

\subsection{Site description}

Measurements were made from the roof of the building that houses the National Center of Investigation and Environmental Qualification (CENICA) on the campus of the Autonomous Metropolitan University in Iztapalapa, Mexico City. Iztapalapa lies in the south-central MCMA, due south of the downtown area by $\sim 7 \mathrm{~km}$. To the west and south of the university are mainly residential areas; to the north and east are several factories and industries.

Northerly (southward) wind generally brings air from the downtown to this site during daytime. The winds from all other directions bring air from the surrounding suburbs to the site. In contrast to mid-latitude megacities, high pollution episodes can occur year-round in the MCMA because the subtropical highs that dominate the weather throughout the year are conducive to active photochemistry. During the winter and spring months, the area is normally under an an- ticyclone with light winds and clear skies. As a result, strong surface-based inversions usually persisted several hours into the morning. Strong solar heating eventually breaks down the inversion and pollutants then mix into a very deep boundary layer $2-4 \mathrm{~km}$ deep. This study was held in April to avoid the wetter summer months (June-September) because clouds and precipitation inhibit strong photochemistry (Molina and Molina, 2002). However, in 2003, the summertime pattern began in April, resulting in frequent clouds and some rain in the afternoon.

\subsection{GTHOS (Ground-based Tropospheric Hydrogen Ox- ides Sensor)}

$\mathrm{OH}$ and $\mathrm{HO}_{2}$ were measured by the Penn State Ground-based Hydrogen Oxides Sensor, called GTHOS. A brief description of the measurement technique and instrument is given here; a full description can be found in Faloona et al. (2004). GTHOS measurement of $\mathrm{OH}$ and $\mathrm{HO}_{2}$ is based on FAGE (Fluorescence Assay by Gas Expansion) (Hard et al., 1984). The air sample is drawn through an orifice $(1.0 \mathrm{~mm}$ diameter $)$ into a low-pressure chamber at a pressure of $4-5 \mathrm{hPa}$. As the air passes through a laser beam, $\mathrm{OH}$ is excited by the laser and then detected at a wavelength near $308 \mathrm{~nm}$. Collisional quenching of the excited state is slow enough at the chamber pressure that the weak $\mathrm{OH}$ fluorescence extends beyond the prompt scattering (Rayleigh and wall scattering) and is detected with a time-gated microchannel plate (MCP) detector.

$\mathrm{OH}$ is detected in the first of two detection axes. In a second axis, $\mathrm{HO}_{2}$ is chemically converted to $\mathrm{OH}$ by reaction with reagent NO that is added to the flow between the two axes. The resultant $\mathrm{OH}$ is then detected by LIF. The laser wavelength is turned on and off resonance with an $\mathrm{OH}$ transition every $10 \mathrm{~s}$. The $\mathrm{OH}$ fluorescence signal is the difference between on-resonance and off-resonance signals.

GTHOS was calibrated before, during, and after the study using the techniques described in Faloona et al. (2004). The upper-limit of the absolute calibration uncertainty was estimated at $\pm 32 \%$ (at the $95 \%-2 \sigma-$ confidence level). The $\mathrm{OH}$ detection limit can be defined as twice the standard deviation of the background signal and was 0.01 part per trillion by volume, or pptv, $\left(\sim 2 \times 10^{5} \mathrm{~cm}^{-3}\right)$ for a 1-min integration period. The $\mathrm{HO}_{2}$ detection limit (with $2 \sigma-$ confidence, 1-min integration time) was estimated to be $0.1 \mathrm{pptv}$ $\left(\sim 2.0 \times 10^{6} \mathrm{~cm}^{-3}\right)$.

During the campaign in Mexico City, GTHOS was mounted approximately $18 \mathrm{~m}$ above the ground on the third level of a scaffolding tower (Fig. 1). Ambient air was pulled through the system by a vacuum pump that was located directly beneath the measurement tower. The electronics and calibration equipment were housed in an air-conditioned hut that was directly adjacent to the tower. 


\subsection{TOHLM (Total OH Loss Measurement)}

The first-order $\mathrm{OH}$ loss rate, called the $\mathrm{OH}$ reactivity, was measured with the Total $\mathrm{OH}$ Loss Measurement instrument (TOHLM) (Kovacs and Brune, 2001; Kovacs et al., 2003; Di Carlo et al., 2004). It was mounted on the first level of the tower, approximately $14 \mathrm{~m}$ above the ground. The inlet hose for TOHLM was mounted just below the inlet of GTHOS on the third level of the tower.

The TOHLM method is analogous to the discharge-flow technique used in laboratory kinetics studies. $\mathrm{OH}$ is generated at mixing ratios of a few 10's of parts per trillion by volume (pptv) by ultraviolet light from a mercury lamp. This light photodissociates water vapor, creating $\mathrm{OH}$ and $\mathrm{H}$ in a nitrogen flow inside a $1-\mathrm{cm}$ diameter movable tube. $\mathrm{H}$ rapidly reacts with trace $\mathrm{O}_{2}$ in the $\mathrm{N}_{2}$ to form $\mathrm{HO}_{2}$. This moveable tube is in the center of a $7.5-\mathrm{cm}$ diameter glass flow tube through which ambient air is drawn by a fan with a total sampling flow rate of about $1401 \mathrm{~min}^{-1}$ and a residence time of $0.1-0.4 \mathrm{~s}$. The $\mathrm{OH}$ is injected through radially drilled holes at the end of the movable tube, mixed turbulently into the air flow, and detected by an $\mathrm{OH}$ detector at the end of the flow tube. The detection technique is low-pressure laser induced fluorescence, as is used for GTHOS. OH reacts with trace constituents in the air flow and, as the movable tube is drawn further away from the detector, the observed $\mathrm{OH}$ signal decreases.

The $\mathrm{OH}$ reactivity, $\mathrm{k}_{\mathrm{OH}}$, is the slope of the logarithm of the $\mathrm{OH}$ signal, $\mathrm{S}^{\mathrm{OH}}$, as function of the time (the distance divided by the velocity) minus the $\mathrm{OH}$ loss to the flow tube's walls, $\mathrm{k}_{\mathrm{wall}}$ :

$k_{\mathrm{OH}}=-\Delta \ln \left(S^{\mathrm{OH}}\right) / \Delta$ time $-k_{\mathrm{wall}}$

Each decay took $4.3 \mathrm{~min}$, with $20 \mathrm{~s}$ at each of $13 \mathrm{steps}, 10 \mathrm{~s}$ measuring $\mathrm{OH}$ plus the background signal and $10 \mathrm{~s}$ measuring the background signal. The $\mathrm{OH}$ signal decreased by a factor of 10-20 over the 13 steps. The measured $\mathrm{OH}$ wall loss rate, $\mathrm{k}_{\mathrm{wall}}$, was $1.5 \pm 0.4 \mathrm{~s}^{-1}$. This measured value was the same before, during, and after the study. Generally, $\mathrm{OH}$ mixing ratios were $10-30$ pptv inside the glass tubing.

\subsection{TOHLM correction technique}

Kovacs et al. (2003) and Ren et al. (2003a) discuss the need to correct $\mathrm{OH}$ reactivity measurements for the $\mathrm{OH}$-recycling reaction:

$\mathrm{HO}_{2}+\mathrm{NO} \rightarrow \mathrm{OH}+\mathrm{NO}_{2}$

When levels of NO are below 1 ppbv, the measured decays are generally linear and the slopes correct to within $10 \%$ (Kovacs et al., 2003). However, when ambient levels of NO are higher, the decays have concave curvature as $\mathrm{HO}_{2}$ reacts with the NO to reform $\mathrm{OH}$. In past studies where the TOHLM instrument was used, NO concentrations infrequently reached levels that required significant corrections or measurements

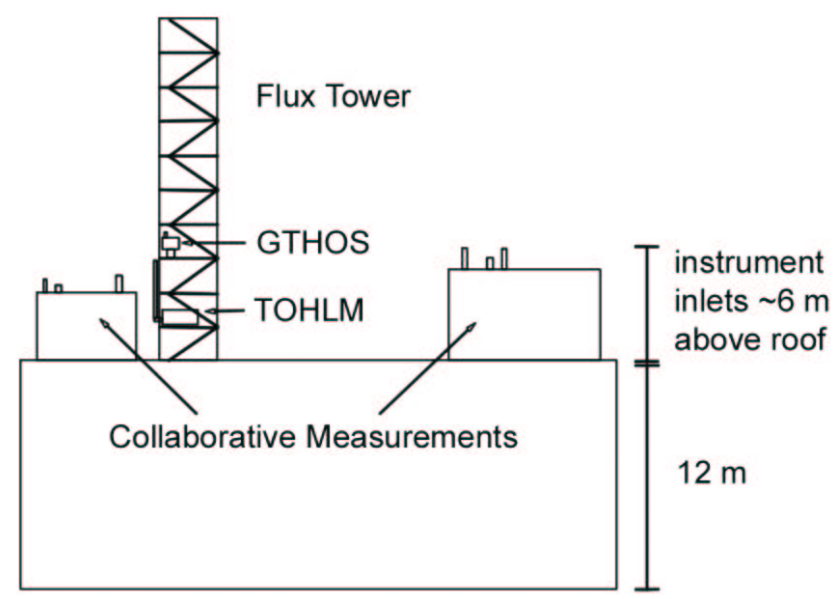

Fig. 1. Schematic of the instruments on the CENICA building roof. Both the Penn State instruments (GTHOS and TOHLM) were on the flux tower with their inlets within $1 \mathrm{~m}$ of one another. Collaborative measurements were also taken on the rooftop by other research groups.

from those times were excluded from further analysis. However, in MCMA during rush hour (05:00-09:00 CST), NO exceeded 50 ppbv $40 \%$ of the time and 100 ppbv $12 \%$ of the time. This frequent contamination of the decays led to a need for a new correction technique that allows $\mathrm{k}_{\mathrm{OH}}$ to be measured at much higher values of NO than earlier methods (Kovacs et al., 2003).

The rate equation for $[\mathrm{OH}]$ is given by the expression:

$$
\begin{aligned}
\frac{d[\mathrm{OH}]}{d t} & =-k_{\mathrm{OH}}[\mathrm{OH}]+k_{\mathrm{NO}+\mathrm{HO} 2}[\mathrm{NO}]\left[\mathrm{HO}_{2}\right] \\
& =-k_{\mathrm{OH}}[\mathrm{OH}]+k_{\mathrm{NO}+\mathrm{HO} 2}[\mathrm{NO}] \mathrm{R}[\mathrm{OH}]
\end{aligned}
$$

where $\mathrm{k}_{\mathrm{OH}}$ is the $\mathrm{OH}$ reactivity $\left(\mathrm{s}^{-1}\right)$ and $\mathrm{R}$ is the measured $\left[\mathrm{HO}_{2}\right] /[\mathrm{OH}]$ ratio. Assuming that the average value for $\mathrm{R}$ can be used for each time step, this expression can be integrated to give the value of $[\mathrm{OH}]$ at time step $t_{1}$ :

$$
\begin{aligned}
{[\mathrm{OH}]_{1}=} & {[\mathrm{OH}]_{0} \exp \left(-k_{\mathrm{OH}}\left(t_{1}-t_{0}\right)\right) \times } \\
& \exp \left(+k_{\mathrm{HO} 2+\mathrm{NO}}[\mathrm{NO}] \mathrm{R}\left(t_{1}-t_{0}\right)\right)
\end{aligned}
$$

The desired $[\mathrm{OH}]$ value is given by the expression $[\mathrm{OH}]_{0}$ $\exp \left(-\mathrm{k}_{\mathrm{OH}}\left(t_{1}-t_{0}\right)\right)$. Thus the corrected $[\mathrm{OH}]$ at time $\mathrm{t}_{1}$ is given by the expression:

$$
[\mathrm{OH}]_{1}^{c}=[\mathrm{OH}]_{1} \exp \left(-\frac{k_{\mathrm{NO}+\mathrm{HO} 2}[\mathrm{NO}]\left[\mathrm{HO}_{2}\right]_{0,1}\left(t_{1}-t_{0}\right)}{[\mathrm{OH}]_{0,1}}\right)
$$

where $[\mathrm{OH}]_{0,1}$ and $\left[\mathrm{HO}_{2}\right]_{0,1}$ are average concentrations of times 0 and 1 . Since the observed $\mathrm{OH}$ and $\mathrm{HO}_{2}$ signals are proportional to $[\mathrm{OH}]$ and $\left[\mathrm{HO}_{2}\right]$ by the calibration factors, $\mathrm{C}_{\mathrm{OH}}$ and $\mathrm{C}_{\mathrm{HO}}$, which for TOHLM are the same, the $\mathrm{OH}$ signal can be corrected for the first time step by the expression:

$S_{1}^{c}=\exp \left[-\left(\Delta S_{1} / S_{0,1}\right)\right] \times S_{1}$ 


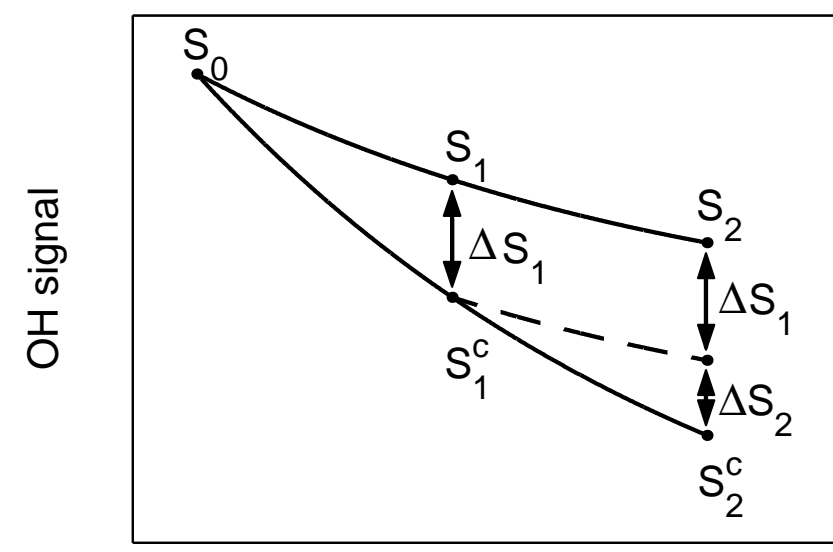

Time

Fig. 2. An example of correcting an $\mathrm{OH}$ decay for $\mathrm{NO}$ interference. The top curve represents the $\mathrm{OH}$ decay with NO interference; the bottom curve is the corrected decay.

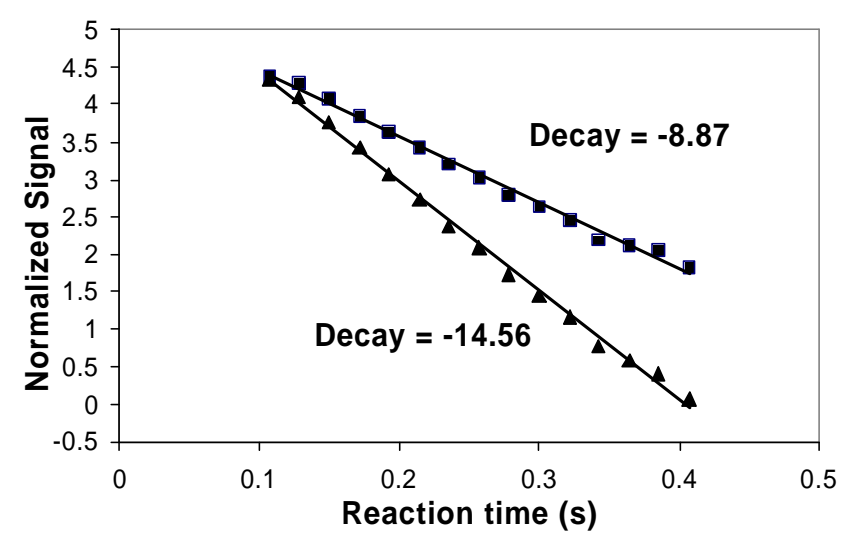

Fig. 3. Laboratory test of the NO correction technique with an average NO concentration of $76.5 \mathrm{ppbv}$. The top curve represents the original $\mathrm{OH}$ decay (squares) with a calculated decay rate of $8.9 \mathrm{~s}^{-1}$; the bottom curve is the corrected $\mathrm{OH}$ decay (triangles) with a calculated decay rate of $14.6 \mathrm{~s}^{-1}$. The theoretical decay rate is $14.9 \mathrm{~s}^{-1}$.

where $\Delta S_{1}=\mathrm{k}_{\mathrm{NO}+\mathrm{HO} 2}[\mathrm{NO}] \mathrm{S}_{0,1}^{\mathrm{HO} 2}\left(\mathrm{t}_{1}-\mathrm{t}_{0}\right)$ and $\mathrm{S}_{0,1}^{\mathrm{HO} 2}$ is the averaged $\mathrm{HO}_{2}$ signal for times $\mathrm{t}_{0}$ and $\mathrm{t}_{1}$.

In order to correct subsequent points, we must realize that the points are not independent of one another. Points $S_{1}$ and $S_{2}$ are then scaled by $S_{1}^{c}$ by multiplying by $S_{1}^{c} / S_{1}$, so that the slope between $S_{1}$ and $S_{2}$ is preserved but the starting point is $\mathrm{S}_{1}^{c}$ (Fig. 2). The correction given in Eq. (4) is then applied to $S_{2}$ and the equation for $S_{2}^{c}$ takes the form:

$S_{2}^{c}=\exp \left[-\left(\Delta S_{1} / S_{0,1}\right)\right] \times \exp \left[-\left(\Delta S_{2} / S_{1,2}\right)\right] \times S_{2}$

where $\exp \left[-\left(\Delta \mathrm{S}_{1} / \mathrm{S}_{0,1}\right)\right]$ is simply the $\mathrm{S}_{1}^{c} / \mathrm{S}_{1}$ that was calculated in Eq. (5). Each subsequent point is calculated in this manner assuring that each point is scaled to the one before it.

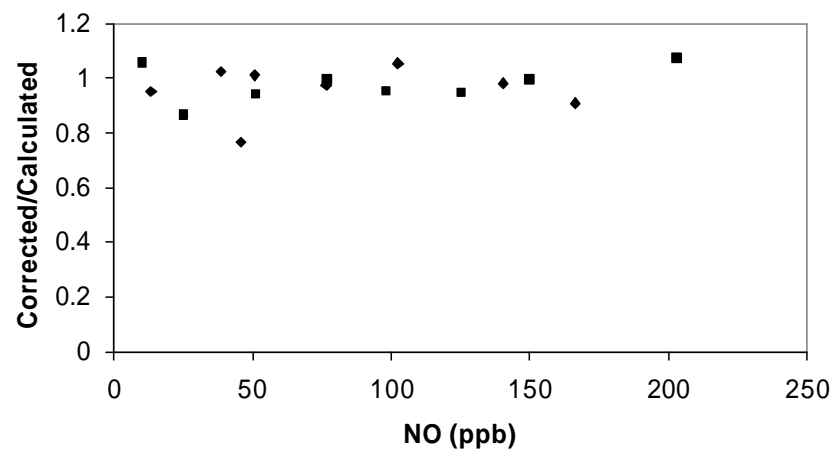

Fig. 4. The ratio of corrected $\mathrm{OH}$ decays to the theoretical calculated decays for a wide range of NO values. Decays with just NO (diamonds) and with NO and CO (squares) are both corrected to the expected value with this technique.

This correction technique was tested in the laboratory (Fig. 3). In this example, NO was $\sim 75$ ppbv, a normal rushhour value for Mexico City. The theoretical calculated decay from the NO and ultra zero air mixture is $14.9 \mathrm{~s}^{-1}$. The uncorrected decay, $8.87 \mathrm{~s}^{-1}$, only $60 \%$ of what is calculated, while the corrected decay is $14.6 \mathrm{~s}^{-1}$. Agreement between the calculated and corrected decays is well within the uncertainties of the TOHLM technique and the reaction rate coefficient for $\mathrm{OH}+\mathrm{NO}+\mathrm{M} \rightarrow \mathrm{HONO}+\mathrm{M}$.

This correction technique was used on a wide range of NO concentrations, from 10-200 ppbv (Fig. 4). To ensure that this technique would work when other reactants were present, several different concentrations of $\mathrm{CO}$ were added to the instrument along with the NO. In all but one case (with and without the addition of $\mathrm{CO}$ ) the corrected $\mathrm{OH}$ decays were within $15 \%$ of the theoretical values. However, the correction factor for decays when $\mathrm{NO}>100 \mathrm{ppbv}$ grows to a factor of $\sim 2-3$ and becomes more uncertain, since small errors in $\mathrm{S}^{\mathrm{HO} 2} / \mathrm{S}^{\mathrm{OH}}$ ratio and in $\mathrm{NO}$ become more important. Using estimates of the uncertainties in these two terms and considering the number of points used in the decays, we estimate that the uncertainty in the correction is $\sim 10 \%, 1 \sigma$ confidence. Because the correction for $75 \mathrm{ppbv}$ of NO is roughly 1.7 , the total absolute uncertainty for the corrected $\mathrm{OH}$ reactivity is $\pm 25 \%, 1 \sigma$ confidence, for $75 \mathrm{ppbv}$ of NO.

\subsection{Brief descriptions of other measurements}

During the MCMA campaign the following ancillary data were continuously measured, with the uncertainties and limit of detection for $10 \mathrm{~min}$ in parentheses: $\mathrm{O}_{3}( \pm 15 \%, 3 \mathrm{ppbv})$, $\mathrm{CO}( \pm 15 \%, 30 \mathrm{ppbv}), \mathrm{SO}_{2}( \pm 20 \%, 0.5 \mathrm{ppbv}), \mathrm{NO}( \pm 15 \%$, $0.1 \mathrm{ppbv}), \mathrm{NO}_{2}( \pm 25 \%, 0.1 \mathrm{ppbv}), \mathrm{CH}_{4}( \pm 5 \%, 0.2 \mathrm{ppmv})$, HCHO ( $\pm 25 \%, 1 \mathrm{ppbv})$, HONO $( \pm 10 \%, 0.15 \mathrm{ppbv})$, temperature, pressure, relative humidity, wind speed, wind direction, and solar ultraviolet radiation. Of these, all but $\mathrm{HCHO}$ and $\mathrm{HONO}$ were in situ measurements collocated on 
the rooftop of the CENICA building with the $\mathrm{HO}_{\mathrm{x}}$ measurements. Photolysis frequencies were either measured with a spectroradiometer $( \pm(3-10) \%)$ when available (Volkamer et al., 2005) or calculated with the NCAR TUV transfer model and scaled by measured solar UV radiation $( \pm 20 \%)$.

$\mathrm{HCHO}$ and $\mathrm{HONO}$ were made over a $4.4 \mathrm{~km}$ path $70 \mathrm{~m}$ above the surface (Volkamer et al., 2005). A comparison of other atmospheric constituents that were measured by both in situ and longpath techniques showed the following relationships: $[\mathrm{CO}]_{\text {in }}-$ situ $=0.96 \times[\mathrm{CO}]_{\text {long }- \text { path }}+0.1$ ppmv, with $\mathrm{R}^{2}=0.93$ (Dunlea et al., 2006); $\left[\mathrm{O}_{3}\right]_{\text {in-situ }}=1.13 \times\left[\mathrm{O}_{3}\right]_{\text {long-path }}-$ $4.6 \mathrm{ppbv}$, with $\mathrm{R}^{2}=0.95$ (Dunlea et al., 2006); and $\left[\mathrm{NO}_{2}\right]_{\text {in }- \text { situ }}=1.04 \times\left[\mathrm{NO}_{2}\right]_{\text {long }- \text { path }}+8.6 \mathrm{ppbv}$, with $\mathrm{R}^{2}=0.81$. These differences are within the measurement uncertainties. Because $\mathrm{HCHO}$ has a lifetime similar to $\mathrm{O}_{3}$ and $\mathrm{NO}_{2}$ in MCMA, the long-path HCHO measurement should be representative of HCHO at CENICA. For HONO, which is an important $\mathrm{OH}$ source and sink mainly during morning rush hour when $\mathrm{OH}$ is low, both of its precursor gases $\mathrm{OH}$ and NO should generally be fairly uniformly distributed, since $\mathrm{NO}_{2}$ is. This result is consistent with the conclusion of Dunlea et al. (2006) that "spatial and temporal inhomogeneities were not substantially influencing comparisons of the point sampling and open path instruments." Thus, the long-path measurements of $\mathrm{HCHO}$ and $\mathrm{HONO}$ and the in situ measurements can be combined in steady state analyses and modeling with only a small increase in the overall uncertainty.

Speciated VOCs were measured during MCMA 2003 by GC-FID automated analysis of samples collected for usually $30 \mathrm{~min}$ in stainless steel canisters (Lamb et al., 2004). The measurements were taken at five sites within the MCMA basin with the goal of determining the spatial variability of total VOC carbon and of the fractions of speciated VOCs. These measurements included 11 alkenes, 26 alkanes, 11 aromatics, along with MTBE, ethyl ester, and styrene. The measurement uncertainty was typically $\pm 20 \%$. About $60 \%$ of the 120 samples were taken during morning rush hour (05:00-10:00 CST) and most of the remainder during other daylight hours. At CENICA, $75 \%$ of the 44 measurements were during morning rush hour. Only two samples were taken at CENICA while the $\mathrm{OH}$ reactivity instrument was operating. However, continuous fast total olefin measurements that were made at CENICA every $6 \mathrm{~s}$ simultaneously with $\mathrm{HO}_{\mathrm{x}}$ and $\mathrm{OH}$ reactivity measurements (Velasco et al., 2005) provide another check on the variability of VOC speciation at CENICA.

\subsection{Models for analysis of the measurements}

Two types of models were used to determine if the measured $\mathrm{OH}$ and $\mathrm{HO}_{2}$ are consistent with the understanding of atmospheric oxidation chemistry in the photochemically active MCMA region. One model is a set of simple algebraic ex- pressions based on steady-state assumptions and using measurements. The other is steady-state photochemical model that is constrained by all the measurements, except $\mathrm{OH}$ and $\mathrm{HO}_{2}$, which are calculated, along with a few other radicals for which there were no measurements.

The Regional Atmospheric Chemistry Mechanism (RACM) (Stockwell et al., 1997) was used to calculate the $\mathrm{OH}$ and $\mathrm{HO}_{2}$ concentrations. Kinetic rate coefficients were updated using the results by Sander et al. (2003). Reactions of $\mathrm{O}_{3}$ with alkenes have been largely revised to represent latest radical yields suggested by recent experiments (Paulson et al., 1999; Rickard et al., 1999; Fenske et al., 2000). Heterogeneous reactions of $\mathrm{HNO}_{3}, \mathrm{SO}_{3}$, and $\mathrm{N}_{2} \mathrm{O}_{5}$ were included in the model. The assumption of steady-state certainly applies to $\mathrm{OH}$, which had a lifetime shorter than $0.1 \mathrm{~s}$ and generally to $\mathrm{HO}_{2}$, which has a lifetime less than a few 10 s of seconds.

The model was run with the FACSIMILE software (UES Software Inc). Model input was constrained to the tenminute average values of $\mathrm{O}_{3}, \mathrm{NO}, \mathrm{NO}_{2}, \mathrm{CO}, \mathrm{SO}_{2}, \mathrm{HCHO}$, other OVOCs, VOC speciation types found by the process described below, water vapor, temperature, pressure, and photolysis frequencies. The data coverage allowed model calculations only for the period between 14 April and 22 April. $\mathrm{OH}, \mathrm{HO}_{2}, \mathrm{NO}_{3}$, organic peroxyl radicals $\left(\mathrm{RO}_{2}\right)$, and other intermediates were calculated. The uncertainty in this RACM model was estimated to be $\pm 45 \%$ for $\mathrm{OH}$ and $\pm 70 \%$ for $\mathrm{HO}_{2}$, with $2 \sigma$ confidence. These uncertainties are based on the combined uncertainties of the kinetic rate coefficients (Sander et al., 2003; Stockwell et al., 1997), the measured chemical concentrations, and the measured and calculated photolysis frequencies, as estimated with a Monte Carlo approach (as in Carslaw et al., 1999).

The measurement suite at CENICA was fairly complete, although speciated VOCs were measured infrequently and were not being measured at CENICA when $\mathrm{HO}_{\mathrm{x}}$ and $\mathrm{OH}$ reactivity were, except for two points. During that time they were being measured at other urban sites. Fortunately, the $\mathrm{OH}$ reactivity measurement gives us information about the total amount of VOCs; all that is needed is information about the typical VOC speciation types throughout the day. We employ the same strategy for the MCMA-2003 study that we did for two other recent studies (Ren et al., 2005, 2006). To get the VOC speciation type inputs to the model, the information from the measured $\mathrm{OH}$ reactivity was used along with the mean fractions of VOCs types combined from CENICA and three other sites. This combined data set provided full daytime and limited night-time coverage.

What makes this approach feasible is the fairly constant fractions of VOC speciation types despite large variations in the total VOCs. Despite the large variation in total organic carbon, the fraction of VOC speciation types (alkanes, alkenes, aromatics, alkynes, oxygenates) remained the same to less than a factor of two for samples taken from the four most urban sites. For any given time period, the day-to-day 

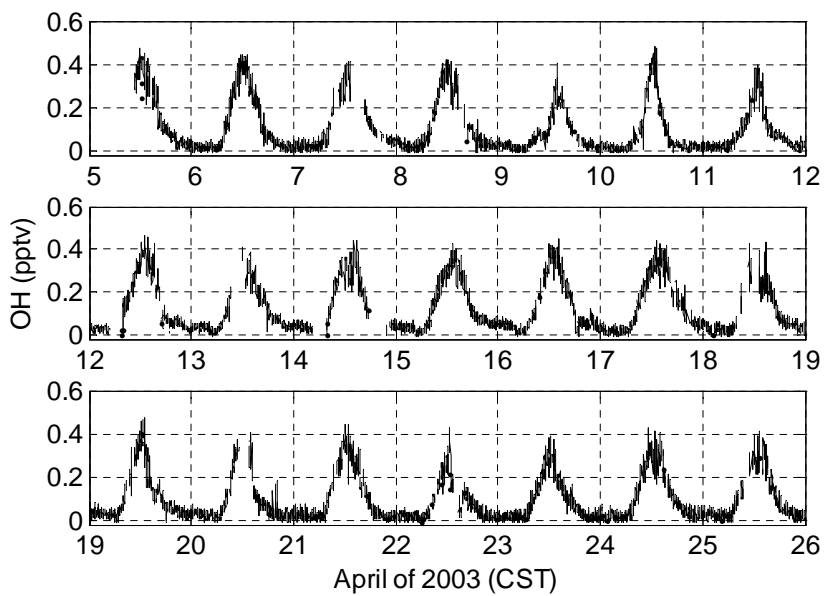

Fig. 5. Time series in CST of all 1-min averaged measured $\mathrm{OH}$ (line). Breaks in the data are usually for calibrations. The absolute $2 \sigma$ uncertainty is $\pm 32 \%$.

scatter in the VOC speciation type measurements for a site was much greater than the differences between sites in the median values for each site. Thus, while plumes and local sources of specific VOCs probably influenced each site, the fraction of VOC speciation types on hour time scales appear to have been uniform to within $\pm 50 \%$ for VOC speciation types at the four measurement sites. Additional evidence of this uniformity comes from the fast olefin measurements (B. Lamb, private communication, 2005). The ratio of $\mathrm{OH}$ reactivity to fast olefins, when averaged over $30 \mathrm{~min}$, is constant during the day to within $\pm 50 \%$. No matter how this issue is examined, the result is that the 30-min speciation does not generally change more than $\pm 50 \%$ throughout the day except for in occasional plumes.

The speciated VOCs were averaged for each half-hour that they were measured and summed into VOC speciation types (e.g., internal alkenes) that the model uses. For the model calculations, the abundance for each VOC speciation type was determined by assigning the same fraction of the measured $\mathrm{OH}$ reactivity from VOCs to that VOC speciation type and then calculating the VOC speciation type's abundance from that fraction of the $\mathrm{OH}$ reactivity divided by the reaction rate coefficient. This method should work in an average sense. This method has been shown to give good results between measured and modeled $\mathrm{HO}_{\mathrm{x}}$ in other studies (Ren et al., 2005, 2006).

Comparisons between $\mathrm{HO}_{\mathrm{x}}$ measurements and calculations from the model constrained this way can test the understanding of $\mathrm{HO}_{\mathrm{x}}$ photochemical sources and the $\mathrm{HO}_{\mathrm{x}}$ dependence on $\mathrm{NO}$ and enables the calculation of the instantaneous ozone production rate, $\mathrm{P}\left(\mathrm{O}_{3}\right)$, if the modeled $\mathrm{HO}_{\mathrm{x}}$ is not too sensitive to the chosen VOC speciation types. To test for this sensitivity, a Monte Carlo approach was taken. The fractions of all but one VOC speciation types were randomly varied over the ranges observed in the speciated VOC
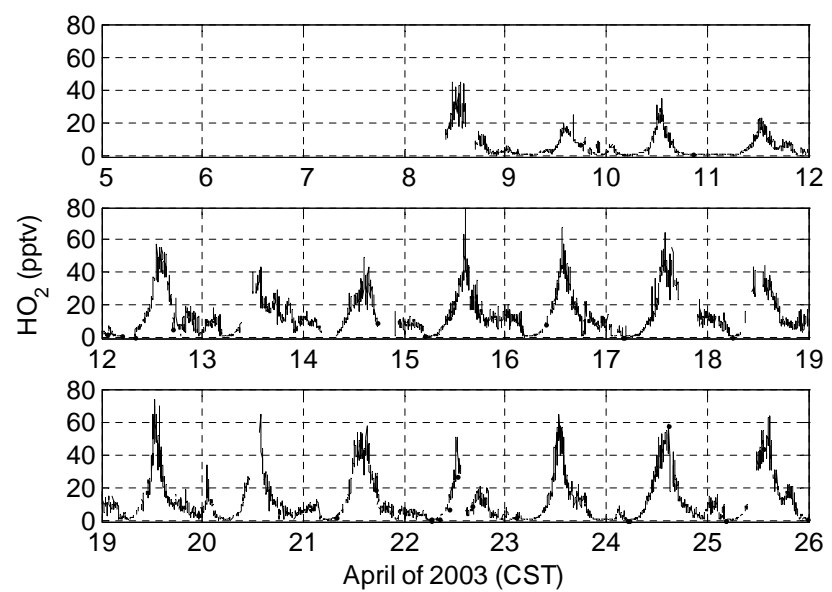

Fig. 6. Time series in CST of all 1-min averaged measured $\mathrm{HO}_{2}$ (line). Breaks in the data are usually for calibrations. The absolute $2 \sigma$ uncertainty is $\pm 32 \%$.

measurements. The fraction for the VOC speciation type that was not varied was then adjusted so that the sum of the fractions was equal to $1 . \mathrm{OH}$ and $\mathrm{HO}_{2}$ were then calculated. This process was repeated 100 times for each half hour to give a diurnal profile of the range of calculated $\mathrm{OH}$ and $\mathrm{HO}_{2}$. This method gives a good assessment of the sensitivity of the modeled $\mathrm{OH}$ and $\mathrm{HO}_{2}$ to the uncertainties in the VOC speciation.

\section{Results and discussion}

MCMA 2003 was an excellent opportunity to study the atmospheric chemistry of a megacity that has improving air quality but still more air pollution than a typical U.S. or European city. A goal of MCMA 2003 was a better understanding of the sources and chemical transformations of MCMA's air pollution.

\section{1 $\mathrm{OH}$ and $\mathrm{HO}_{2}$ : measured values}

$\mathrm{OH}$ was measured on 21 days in Mexico City from 5 April to 26 April 2003 (Fig. 5); $\mathrm{HO}_{2}$ was measured on 18 days from 8 April to 26 April 2003 (Fig. 6). The NO addition to the $\mathrm{HO}_{2}$ axis was deliberately delayed so that any potential interference that it might cause and $\mathrm{OH}$ interference could be detected as a change in the $\mathrm{OH}$ measurement. No change was detected. $\mathrm{OH}$ was fairly consistent from day-to-day, with midday peak values of $0.25-0.4 \mathrm{pptv}$ ((5$\left.8) \times 10^{6} \mathrm{~cm}^{-3}\right)$. The effects of clouds on $\mathrm{OH}$ production can be seen in the reduction in $\mathrm{OH}$ on several afternoons. Variability was greater for $\mathrm{HO}_{2}$ than for $\mathrm{OH}$. Peak $\mathrm{HO}_{2}$ varied from $15 \mathrm{pptv}\left(\sim 3 \times 10^{8} \mathrm{~cm}^{-3}\right)$ to $60 \mathrm{pptv}\left(\sim 12 \times 10^{8} \mathrm{~cm}^{-3}\right)$.

The $\mathrm{HO}_{2}$ peak is narrower than the $\mathrm{OH}$ peak and is shifted one hour later. $\mathrm{HO}_{2}$ persisted at $\sim 5 \mathrm{pptv}$ ( 0.5 to $20 \mathrm{pptv}$ ) during the night. $\mathrm{HO}_{2}$ has a diurnal profile that peaked at 

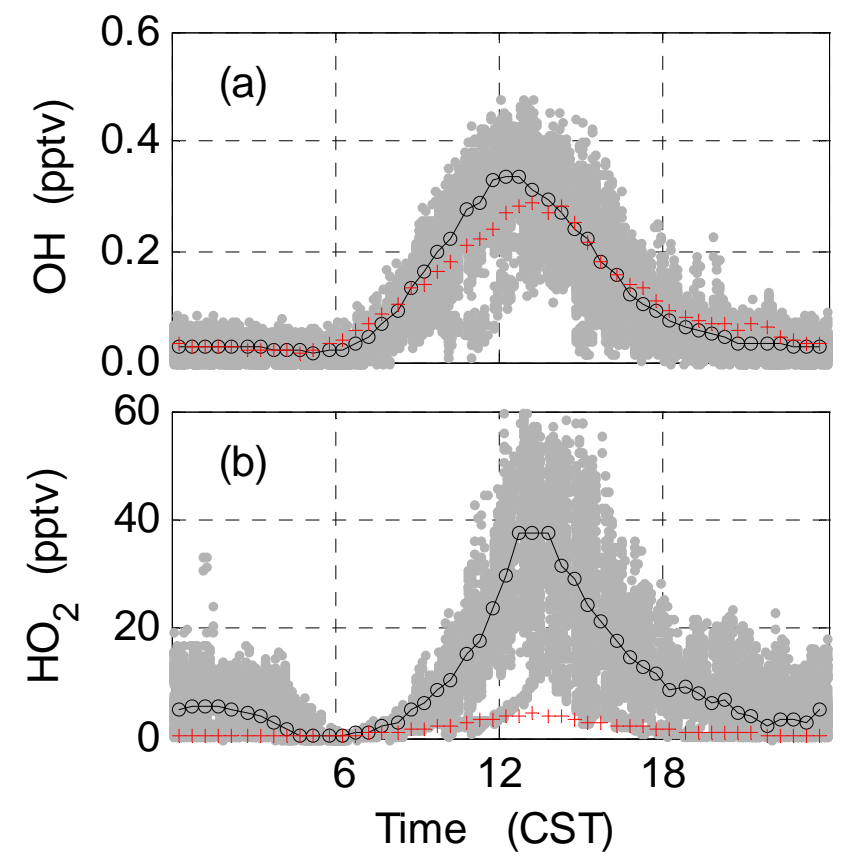

Fig. 7. Diurnal variation of $\mathrm{OH}$ and $\mathrm{HO}_{2}$ for MCMA between 11 April and 21 April. (a): Measured $\mathrm{OH}$ in MCMA (solid line) and in NYC (plusses); (b): measured $\mathrm{HO}_{2}$ in MCMA (solid line) and NYC (plusses). Gray dots are individual MCMA measurements.

$\sim 40$ pptv at 13:00, and decreased to less than 0.5 pptv at sunrise, when $\mathrm{HO}_{\mathrm{x}}$ production was just beginning to increase but when copious rush-hour $\mathrm{NO}$ effectively scavenged $\mathrm{HO}_{2}$.

The $\mathrm{OH}$ and $\mathrm{HO}_{2}$ diurnal cycles become more distinct when $\mathrm{OH}$ and $\mathrm{HO}_{2}$ are plotted as a function of time-ofday (Figs. 7a and $\mathrm{b}$ ). The median $\mathrm{OH}$ peaks at $0.35 \mathrm{pptv}$ $\left(\sim 7 \times 10^{6}\right) \mathrm{cm}^{-3}$ at local noon. The nighttime values ranged from $0.05 \mathrm{pptv}\left(\sim 1 \times 10^{6} \mathrm{~cm}^{-3}\right)$ to below the detection limit $\left(0.01 \mathrm{pptv}\right.$ or $\left.2 \times 10^{5} \mathrm{~cm}^{-3}\right)$. The median $\mathrm{HO}_{2}$ peaks at 37.2 pptv and falls off rapidly to less than a few pptv at night, with a minimum at morning rush hour, when NO is rapidly converting $\mathrm{HO}_{2}$ to $\mathrm{OH}$ and $\mathrm{NO}_{2}$ is rapidly converting $\mathrm{OH}$ to $\mathrm{HNO}_{3}$.

\subsection{Comparison between MCMA 2003 and NYC 2001}

The comparison of the observations at MCMA to those in U.S. urban areas is also instructive because most U.S. cities are more advanced in their efforts to reign in air pollution than MCMA is. We compare our MCMA observations to our observations taken in New York City (NYC) in July 2001 (Ren et al., 2003a, b). New York City provides a good comparison because it too is a megacity, but is one with more advanced pollution abatement efforts. The measurements in New York City (NYC) were part of PMTACS-NY (PM2.5 Technology Assessment and Characterization StudyNew York), which was held Queens, NY during July 2001.


Fig. 8. Diurnal variation of pollutants. (a): Median ozone in MCMA 2003 (solid line) and NYC 2001 (plusses). (b): Median $\mathrm{NO}_{\mathrm{x}}$ in MCMA 2003 (solid line) and NYC 2001 (plusses). Gray dots are individual MCMA measurements. (c): Median VOCs from 4 sites in MCMA 2003 (solid line) and NYC 2001 (plusses).

Characteristics of MCMA 2003 and NYC 2001 (Table 1) are discussed and shown in the next paragraphs and figures.

Ozone was significantly greater in MCMA 2003 than in NYC 2001 (Fig. 8a). The median MCMA O 3 peak of $115 \mathrm{ppbv}$ was twice that of NYC. The maximum value occurred closer to local noon by about $2 \mathrm{~h}$ in MCMA than in NYC, suggesting more active morning photochemistry (Volkamer et al., 2005). Nighttime values were similar in the two locations, with minimum ozone at morning rush hour. In both studies, the observed ozone was less than usual due to atypical weather conditions. In NYC during summer 2001, sea breezes were more frequent than usual, bringing cleaner air from the Atlantic Ocean over the site in Queens. In MCMA during April 2003, the typical summer pattern with afternoon clouds and rain set up early.

Ozone production depends on both $\mathrm{NO}_{\mathrm{x}}$ and VOCs. $\mathrm{NO}_{\mathrm{x}}$ was significantly greater in MCMA than in NYC only during morning rush hour (Fig. 8b), when, MCMA's median $\mathrm{NO}_{\mathrm{x}}$ peaked at $86 \mathrm{ppbv}$, about 1.6 times the median peak for NYC's $\mathrm{NO}_{\mathrm{x}}$. During the afternoon, both cities had about 20 ppbv of $\mathrm{NO}_{\mathrm{x}}$. Nighttime $\mathrm{NO}_{\mathrm{x}}$ was typically 20-35 ppbv 
Table 1. Median photochemical characteristics of New York City (NYC), July 2001, and Mexico City Metropolitan Area (MCMA), April 2003.

\begin{tabular}{|c|c|c|}
\hline \multicolumn{3}{|c|}{ Median Properties of NYC 2001 \& MCMA 2003} \\
\hline median characteristic & NYC & MCMA \\
\hline 2004 population $\left(10^{6}\right)$ & 22 & 22 \\
\hline total daily $\mathrm{J}\left(\mathrm{O}^{1} \mathrm{D}\right)$ & 0.59 & 0.81 \\
\hline peak $\mathrm{NO}_{\mathrm{x}}(\mathrm{ppbv})$ & 54 & 86 \\
\hline peak CO (ppbv) & 590 & 2600 \\
\hline peak $\mathrm{O}_{3}$ (ppbv) & 48 & 115 \\
\hline $\mathrm{OH}$ reactivity $\mathrm{kOH}\left(\mathrm{s}^{-1}\right)$ & 20 & 33 \\
\hline $\mathrm{kOH}$ from $\mathrm{NO}_{\mathrm{x}}(\%)$ & 42 & 12 \\
\hline $\mathrm{kOH} / \mathrm{VOC}\left(\mathrm{s}^{-1} \mathrm{ppbC}^{-1}\right)$ VOC (pptv) & 0.02 & 0.07 \\
\hline peak $\mathrm{OH}(\mathrm{ppbv})$ & 0.28 & 0.35 \\
\hline peak $\mathrm{HO}_{2}(\mathrm{ppbv})$ & 4.2 & 37.2 \\
\hline
\end{tabular}

in both cities. In MCMA, the total VOC abundance differed by a factor of 10 for the four different urban sites and varied a factor of 5 during the day at any site (Fig. 8c). The median value for MCMA 2003 was $1230 \mathrm{ppbC}$; the median value for NYC 2001 was $80 \mathrm{ppbC}$. Thus, while MCMA and NYC had $\mathrm{NO}_{\mathrm{x}}$ values different by no more than a factor of two, the big difference was the VOCs, which were about 15 times larger in MCMA than in NYC.

It should be noted that the comparison of surface concentrations distorts the differences in $\mathrm{NO}_{\mathrm{x}}$ and $\mathrm{VOC}$ emissions. The midday mixed layer for MCMA was typically $3-4 \mathrm{~km}$ above the surface, while the mixed layer for NYC was typically 1 to $1.5 \mathrm{~km}$. Because the MCMA mixed layer is greater by about a factor of two or three, MCMA's emissions were substantially greater for both $\mathrm{NO}_{\mathrm{x}}$ and VOCs than NYC's were.

In MCMA, the $\mathrm{OH}$ reactivity, $\mathrm{k}_{\mathrm{OH}}$, had a large peak of $\sim 120 \mathrm{~s}^{-1}$ during morning rush hour, $25 \mathrm{~s}^{-1}$ during midday, and $\sim 35 \mathrm{~s}^{-1}$ at night (Fig. 9). This diurnal behavior is similar to that of $\mathrm{NO}_{\mathrm{x}}$, which is consistent with a large transportation source of both $\mathrm{OH}$ reactivity and $\mathrm{NO}_{\mathrm{x}}$. This behavior contrasts with the $\mathrm{OH}$ reactivity in NYC, which was typically $20 \mathrm{~s}^{-1}$ the entire time, with a only small increase during morning rush hour (Fig. 9). The MCMA morning peak is about 5 times what was found in NYC.

During MCMA 2003, only two VOC samples were taken at CENICA while the $\mathrm{OH}$ reactivity instrument was operating. For these two samples, the measured $\mathrm{OH}$ reactivity was 1.3 times the calculated $\mathrm{OH}$ reactivity, within the combined $2 \sigma$ uncertainties. However, with very little overlap between the measured $\mathrm{OH}$ reactivity and the measured VOCs, it is not possible to examine the completeness of the measured VOCs and other $\mathrm{OH}$ reactants.

The fraction of $\mathrm{OH}$ reactivity due to VOCs can be calculated by subtracting the reactivity due to $\mathrm{NO}, \mathrm{NO}_{2}, \mathrm{O}_{3}, \mathrm{SO}_{2}$,

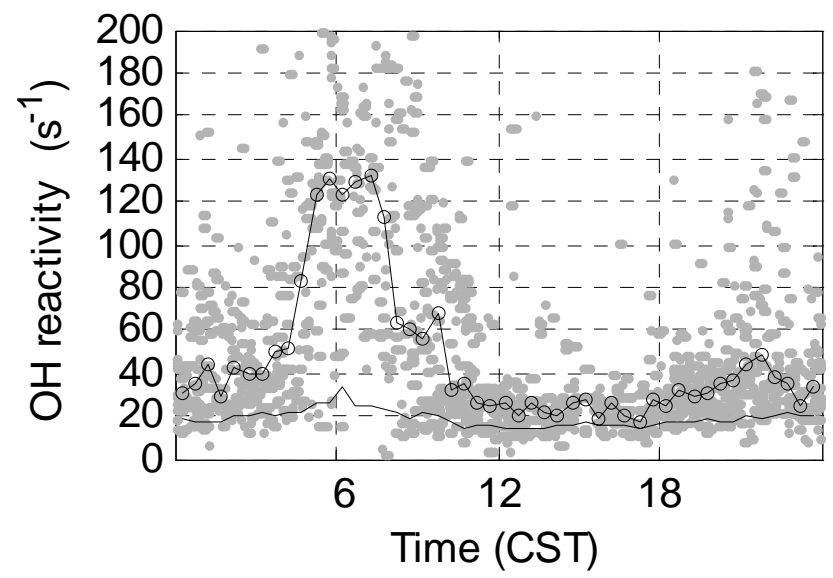

Fig. 9. Diurnal variation of median measured $\mathrm{OH}$ reactivity in MCMA 2003 (connected circles) and NYC 2001 (solid line). Gray points are individual MCMA measurements. The maximum absolute $1 \sigma$ uncertainty is $\pm 25 \%$ during morning rush hour and $\pm 15 \%$ otherwise.

$\mathrm{HO}_{2}, \mathrm{CH}_{4}, \mathrm{HONO}, \mathrm{HCHO}$, and other continuously measured species. From this analysis, for the $\mathrm{OH}$ reactivity in MCMA, $12 \%$ was due to $\mathrm{NO}_{\mathrm{x}}, 7 \%$ to $\mathrm{CO}, 4 \%$ to $\mathrm{HCHO}$. This values are consistent with $72 \%$ of the $\mathrm{OH}$ reactivity coming from VOCs, as was calculated by the model. In contrast, for $\mathrm{OH}$ reactivity in $\mathrm{NYC}, 42 \%$ was due to $\mathrm{NO}_{\mathrm{x}}, 12 \%$ to $\mathrm{CO}$, and $11 \%$ to OVOCs, $40 \%$ of which is due to $\mathrm{HCHO}$, while VOCs contributed $\sim 20 \%$. Examining the OH reactivity due only to VOCs, the median ratio of the $\mathrm{OH}$ reactivity per ppbC of VOCs was $\sim 0.02 \mathrm{~s}^{-1} \mathrm{ppbC}^{-1}$ in MCMA, but was $\sim 0.07 \mathrm{~s}^{-1} \mathrm{ppbC}^{-1}$ in NYC. This difference in the $\mathrm{OH}$ reactivity per VOC carbon is not surprising considering the large abundances of less-reactive alkanes, mainly propane, found in MCMA compared to NYC (Mugica et al., 2003; Parrish et al., 1998; Lamb et al., 2004).

The observed $\mathrm{OH}$ in MCMA is similar to the observed $\mathrm{OH}$ in NYC, despite the large differences in $\mathrm{OH}$ reactivity (Fig. 7a). The peak value in New York City is shifted $2 \mathrm{~h}$ past solar noon, but at 0.28 pptv is only $20 \%$ lower than the average peak $\mathrm{OH}$ for MCMA.

The $\mathrm{HO}_{2}$ in MCMA was generally eight times larger than the $\mathrm{HO}_{2}$ was in NYC (Fig. 7b). This large difference results from the large difference in the $\mathrm{HO}_{\mathrm{x}}$ sources, although the photolysis frequencies were only $40 \%$ greater than in MCMA than NYC. A big difference was the greater amount of HCHO in MCMA. It peaks at $\sim 20 \mathrm{ppbv}$ in the morning (R. Volkamer, private communication, 2005), represents about $40 \%$ of the $\mathrm{HO}_{\mathrm{x}}$ source, and was about 15 times larger in MCMA than in NYC during midday. Ozone, which is twice as large in MCMA as in NYC, also contributed to the difference in $\mathrm{HO}_{\mathrm{x}}$. The $\mathrm{HO}_{\mathrm{x}}$ sink, which was predominantly the reaction $\mathrm{OH}+\mathrm{NO}_{2}+\mathrm{M} \rightarrow \mathrm{HNO}_{3}+\mathrm{M}$, was comparable in the two cities except during morning rush hour, when it was twice as large in MCMA. 
These MCMA $\mathrm{HO}_{\mathrm{x}}$ measurements are a good example of the buffering effects of the $\mathrm{OH}$ production and loss processes. Over the course of the study, $\mathrm{HO}_{2}$ peak values varied greatly from day-to-day, indicating dramatic changes in $\mathrm{HO}_{\mathrm{x}}$ sources, but $\mathrm{OH}$ peak values remained relatively unchanged, as can be seen by comparing Figs. 5 and 6 and by comparing the MCMA and NYC median $\mathrm{HO}_{x}$ values in Fig. 7. That $\mathrm{HO}_{2}$ is much more sensitive to $\mathrm{HO}_{\mathrm{x}}$ sources and sinks than $\mathrm{OH}$ suggests that $\mathrm{HO}_{2}$ must be measured along with $\mathrm{OH}$ to really test and understand the radical chemistry.

\section{$3.3 \mathrm{OH}$ and $\mathrm{HO}_{2}$ : modeled values}

Model calculations of $\mathrm{OH}$ and $\mathrm{HO}_{2}$ were made in the period between 14 April and 22 April, when the measurement suite was the most complete. The measured and modeled $\mathrm{OH}$ and $\mathrm{HO}_{2}$ are compared in the median because of the potential uncertainty introduced by the somewhat limited speciated VOC measurements at CENICA while $\mathrm{OH}$ and $\mathrm{HO}_{2}$ were being measured. However, it is interesting that the comparison of individual 10-min averaged data yields the following relationships between measured and modeled values: $(\mathrm{OH})_{\text {model }}=1.2 \times(\mathrm{OH})-0.008 \mathrm{pptv}$, with $\mathrm{R}^{2}=0.80$ and $\left(\mathrm{HO}_{2}\right)_{\text {model }}=0.90 \times\left(\mathrm{HO}_{2}\right)+0.98$ pptv, with $\mathrm{R}^{2}=0.64$, both within the measurement uncertainties. This good agreement between model and measurement, even for 10-min comparisons, indicates that either the fraction of VOC speciation types is not changing significantly or the changes that are occurring in VOC speciation types are not significant for $\mathrm{OH}$ and $\mathrm{HO}_{2}$ modeling or both.

The median modeled and measured $\mathrm{OH}$ and $\mathrm{HO}_{2}$ show similar behavior (Figs. 10a, b). The measured-to-modeled $\mathrm{OH}$ ratio is 1.07 during morning rush hour (05:0009:00 CST), 0.77 during midday (10:00-14:00 CST), and 1.07 at night (20:00-04:00 CST) (Fig. 10a). The measuredto-modeled $\mathrm{HO}_{2}$ ratio is 1.17 during morning rush hour (05:00-09:00 CST), 0.79 during midday (10:00-14:00 CST), and 1.25 at night (20:00-04:00 CST) (Fig. 10a). Median measurements and models agree with uncertainties for both $\mathrm{OH}$ and $\mathrm{HO}_{2}$.

Using a Monte Carlo approach to vary the VOC speciation over the range of values observed in MCMA, as described in Sect. 2.6, median modeled $\mathrm{OH}$ and $\mathrm{HO}_{2}$ are compared to the median observations (Figs. 10c, d). Close inspection reveals that the entire range of the modeled $\mathrm{OH}$ results is $\pm 15 \%$ during midday and $\pm 45 \%$ for evening and night; the entire range of the modeled $\mathrm{HO}_{2}$ results is $\pm 15 \%$ during the day and $\pm 60 \%$ during the evening and night. These ranges are less than the $\mathrm{OH} 2 \sigma$ modeling uncertainty of $\pm 45 \%$ for $\mathrm{OH}$ and $\pm 70 \%$ for $\mathrm{HO}_{2}$. Because the uncertainties are independent, the total model uncertainty increases insignificantly during the day and about $35 \%$ during the evening and night. The additional uncertainty induced by the observed factor-oftwo variation in the VOC speciation types does not alter any
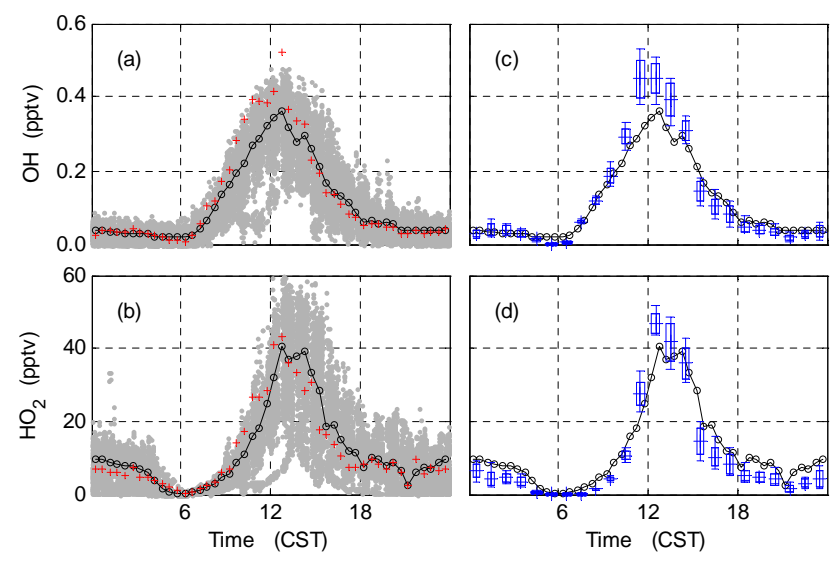

Fig. 10. Diurnal variation of $\mathrm{OH}$ and $\mathrm{HO}_{2}$ for MCMA between 11 April and 21 April. (a): $\mathrm{OH}$ - measured (solid line) and modeled (plusses); (b): $\mathrm{HO}_{2}$ - measured (solid line) and modeled (plusses); (c) $\mathrm{OH}$ - measured (solid line) and modeled with Monte Carlo treatment of speciated VOC fractions, where boxes define standard deviations and error bars define maximum and minimum values; (d) $\mathrm{HO}_{2}$ - measured (solid line) and modeled with Monte Carlo treatment of speciated VOC fractions, where boxes define standard deviations and error bars define maximum and minimum values. Gray dots are individual MCMA measurements. For $\mathrm{OH}$, the absolute $2 \sigma$ uncertainty is $\pm 32 \%$ for the measurements and $\pm 45 \%$ for the model. For $\mathrm{HO}_{2}$, the absolute uncertainty is $\pm 32 \%$ for the measurements and $\pm 70 \%$ for the model.

of our conclusions about the comparisons between measured and modeled $\mathrm{OH}$ and $\mathrm{HO}_{2}$ for MCMA.

Thus, both the VOC speciation types were not changing significantly and the observed factor-of-two changes in VOC speciation types are not significant for modeling $\mathrm{OH}$ and $\mathrm{HO}_{2}$ in MCMA. This result should not be too surprising. The exception is, of course, the occasional plume of air from an atypical source, but even models that ingest hourly VOC samples will likely not model $\mathrm{OH}$ and $\mathrm{HO}_{2}$ correctly unless the plume a stable for more than an hour. Thus, although knowing the typical VOC speciation is important, the greatest changes in VOC that occurred in MCMA were in the VOC abundance, which the $\mathrm{OH}$ reactivity measurement tracked well.

\subsection{The $\mathrm{HO}_{2} / \mathrm{OH}$ ratio as a function of $\mathrm{NO}$}

Examining the $\mathrm{HO}_{2} / \mathrm{OH}$ ratio tests the fast photochemistry that cycles $\mathrm{HO}_{x}$ between these $\mathrm{OH}$ and $\mathrm{HO}_{2}$. The $\mathrm{HO}_{2} / \mathrm{OH}$ ratio is approximately given by the equation:

$$
\frac{\frac{\left[\mathrm{HO}_{2}\right]}{[\mathrm{OH}]}=}{k_{\mathrm{HO} 2+\mathrm{NO}}[\mathrm{NO}]+k_{\mathrm{HO} 2+\mathrm{O} 3}\left[\mathrm{O}_{3}\right]+\mathrm{P}(\mathrm{OH})_{\text {primary }} /\left[\mathrm{HO}_{2}\right]}
$$

where $\mathrm{P}(\mathrm{OH})_{\text {primary }}$ is the $\mathrm{OH}$ produced by every source except cycling through $\mathrm{HO}_{2}$. 


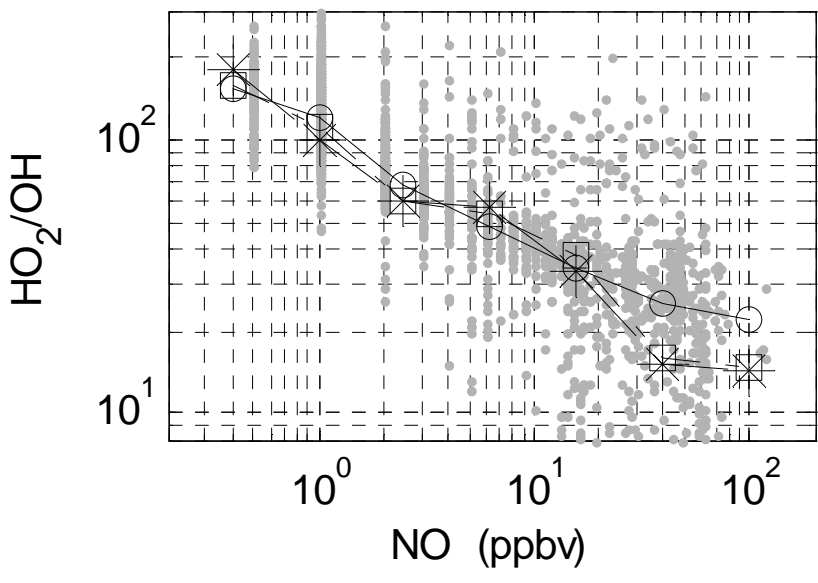

Fig. 11. Dependence $\left[\mathrm{HO}_{2}\right] /[\mathrm{OH}]$ ratio with NO. Measurements (circles and line), modeled using Eq. (7) (squares and dash-dot line), and modeled using RACM (stars and dashed line) are shown. Gray dots are individual 10-min measurements. Lines are added to aid comparison.

For MCMA 2003, midday $\mathrm{HO}_{2} / \mathrm{OH}$ was typically 120 , with low values of 10-15 during morning rush hour and high values of 200 at night (Fig. 11). This behavior is quite different from New York City, where the ratio was typically $\sim 15$ at all times (Ren et al., 2003a). The difference in the midday $\mathrm{HO}_{2} / \mathrm{OH}$ ratio between MCMA and NYC is due to differences in midday $\mathrm{NO}$, which was typically less than $1 \mathrm{ppbv}$ in MCMA but 5 ppbv or higher in NYC, and the midday $\mathrm{OH}$ reactivity, which in MCMA was typically 1.5 times that in NYC. Typically, the reaction of $\mathrm{HO}_{2}$ with $\mathrm{NO}$ is more than 10 times larger than either the reaction of $\mathrm{HO}_{2}$ with $\mathrm{O}_{3}$ or with the primary $\mathrm{OH}$ production divided by $\left[\mathrm{HO}_{2}\right]$. Equation (7) can often be approximated by the expression:

$\frac{\left[\mathrm{HO}_{2}\right]}{[\mathrm{OH}]} \approx \frac{k_{\mathrm{OH}}}{k_{\mathrm{HO} 2+\mathrm{NO}}[\mathrm{NO}]}$

Increasing the numerator in Eq. (8) by 1.5 and decreasing the denominator by $\sim 5$ provides the difference of eight in the MCMA and $\mathrm{NYC} \mathrm{HO}_{2} / \mathrm{OH}$ ratios.

The measured $\mathrm{HO}_{2} / \mathrm{OH}$ ratios display the same dependence on $\mathrm{NO}$ as the ratio obtained from the steady-state expression in Eq. (7) for NO between 1 and $100 \mathrm{ppbv}$ and from the model (Fig. 10). The steady-state expression, which is calculated only from measured quantities, shows the same NO-dependence for $\mathrm{HO}_{2} / \mathrm{OH}$ as the model does. The observed and modeled ratios vary approximately as the $1 / 2$ power of NO, whereas an NO power dependence of 1 to 2 is expected. This less-than-theory power dependence comes from the co-emission with $\mathrm{NO}$ of atmospheric constituents that react with $\mathrm{OH}$, thus increasing $\mathrm{HO}_{2}$. The measured ratio is higher than the modeled ratio when NO exceeds 20 pptv but only by less than a factor of two.

While such good agreement between the measured and modeled ratio is expected, this behavior has not been ob- served in some other urban areas. Typically, the measured $\mathrm{HO}_{2} / \mathrm{OH}$ has had a much shallower slope with respect to $\mathrm{NO}$ than the modeled ratio does, resulting in the measured ratio being as much as ten times larger than the modeled ratio for NO exceeding $10 \mathrm{ppbv}$ (Ren et al., 2003; Martinez et al., 2003; Emmerson, 2005). Neither the reason for the poor agreement in other urban areas nor the reason for the different behavior in MCMA are currently understood.

\section{5 $\mathrm{OH}$ production and loss}

MCMA's OH reactivity of $20 \mathrm{~s}^{-1}$ during most of the day and $120 \mathrm{~s}^{-1}$ at morning rush hour implies $\mathrm{OH}$ lifetimes of $50 \mathrm{~ms}$ to $8 \mathrm{~ms}$. This lifetime is much shorter than the time scales for other processes, including mixing of emissions, changes in photolysis, and other chemistry. As a result, the $\mathrm{OH}$ production should equal the $\mathrm{OH}$ loss:

$$
\begin{aligned}
\mathrm{P}(\mathrm{OH})= & 2 J_{\mathrm{O} 3} f\left[\mathrm{O}_{3}\right]\left[\mathrm{H}_{2} \mathrm{O}\right] \\
& +J_{\mathrm{HONO}}[\mathrm{HONO}]+k_{\mathrm{NO}+\mathrm{HO}_{2}[\mathrm{NO}]\left[\mathrm{HO}_{2}\right]} \\
& +k_{\mathrm{O} 3+\mathrm{VOC}}\left[\mathrm{O}_{3}\right][\mathrm{VOC}]+\text { other smaller terms } \\
= & k_{\mathrm{OH}}[\mathrm{OH}]=\mathrm{L}(\mathrm{OH})
\end{aligned}
$$

where $\mathrm{f}$ is the fraction of $\mathrm{O}\left({ }^{1} \mathrm{D}\right)$ that is produced from $\mathrm{O}_{3}$ photolysis and reacts with $\mathrm{H}_{2} \mathrm{O}$ to produce $\mathrm{OH}$. The $\mathrm{OH}$ loss is determined simply from the product of $[\mathrm{OH}]$ and the $\mathrm{OH}$ reactivity, both of which are measured. Over $80 \%$ of the $\mathrm{OH}$ production is controlled by $\left[\mathrm{HO}_{2}\right]$ and $[\mathrm{NO}]$, both of which are measured. The first three $\mathrm{OH}$ production terms were calculated from measurements; the fourth term, $\mathrm{OH}$ production from $\mathrm{O}_{3}$ and alkenes, was taken from model results and was less than $5 \pm 3 \%$ of the total.

$\mathrm{P}(\mathrm{OH})$ and $\mathrm{L}(\mathrm{OH})$ are in balance to within the combined $2 \sigma$ uncertainties of the $\mathrm{OH}$ production and loss terms (Fig. 12). The difference $\mathrm{L}(\mathrm{OH})-\mathrm{P}(\mathrm{OH})$ should be zero for the entire day, but it is actually slightly negative during morning rush hour (05:00-09:00 CST), implying greater-thanexpected production. Smaller $\mathrm{L}(\mathrm{OH})-\mathrm{P}(\mathrm{OH})$ differences at morning rush hour were observed in Nashville (Martinez et al., 2003) and in New York City (Ren et al., 2003a).

These differences at morning rush hour are not beyond the measurement uncertainties, and yet they are persistent from study to study. For MCMA between 07:00 and 08:00 CST, $\mathrm{OH}$ production is double the $\mathrm{OH}$ loss. Previous attempts to explain these differences with instrumental artifacts for $\mathrm{HO}_{2}$ have failed (Ren et al., 2004); however, it is possible that our laboratory tests of the correction algorithm for $\mathrm{HO}_{2}+\mathrm{NO} \rightarrow \mathrm{OH}+\mathrm{NO}_{2}$ do not apply to MCMA air, with its more complex composition. This explanation, however, seems unlikely.

If the measurements are correct, then the imbalance in the $\mathrm{OH}$ production and loss at morning rush hour indicates problems with known urban photochemistry. We are left with the conclusion that some aspect of the $\mathrm{HO}_{\mathrm{x}}-\mathrm{NO}_{\mathrm{x}}$ photochemistry may need re-examination. One solution would be that 


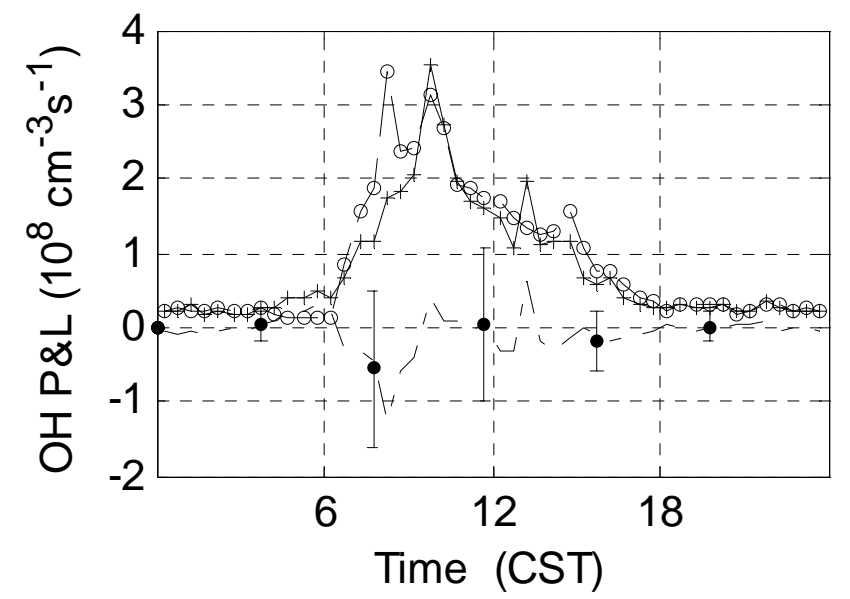

Fig. 12. Diurnal variation of the median $\mathrm{OH}$ production (circles) and median loss (plusses), and median loss - production (dot-dash line) for MCMA. Error bars are $2 \sigma$ absolute uncertainty on $\mathrm{OH}$ loss $-\mathrm{OH}$ production.

some products of the reaction $\mathrm{HO}_{2}+\mathrm{NO}$ are not $\mathrm{OH}+\mathrm{NO}_{2}$. Instead, this imbalance provides evidence that some of the $\mathrm{HO}_{2}+\mathrm{NO}$ reaction results either in $\mathrm{HO}_{\mathrm{x}}$ removal or couples with another reaction that rapidly cycles back to $\mathrm{HO}_{2}$ without going through $\mathrm{OH}$. The uncertainty in the MCMA measurements does not allow us to distinguish between $\mathrm{HO}_{\mathrm{x}}$ removal or rapid cycling. A study of the imbalance in the $\mathrm{NO}_{\mathrm{x}}$ photostationary state led Volz-Thomas et al. (2003) to a similar and possibly related conclusion: an unknown process is converting $\mathrm{NO}$ to $\mathrm{NO}_{2}$ without resulting in ozone production.

\subsection{Instantaneous $\mathrm{O}_{3}$ production}

The net instantaneous $\mathrm{O}_{3}$ production is in some ways a better indicator of the connection between ozone precursors and ozone than is the ozone mixing ratio itself (Kleinman et al., 2000). Instantaneous ozone production is not subject to the uncertainties in physical processes like horizontal advection, planetary boundary layer height changes, entrainment of free-tropospheric air, and dry deposition. On the other hand, because it does not take these physical processes into account, it is a poor indicator of the actual ozone mixing ratios that will occur. Nevertheless, it does provide insight into the chemical processes that create ozone at the CENICA site.

The net instantaneous photochemical $\mathrm{O}_{3}$ production can be calculated by the equation:

$$
\begin{aligned}
\mathrm{P}\left(\mathrm{O}_{3}\right)= & k_{\mathrm{HO} 2+\mathrm{NO}}[\mathrm{NO}]\left[\mathrm{HO}_{2}\right]+\Sigma k_{\mathrm{RO} 2 \mathrm{i}+\mathrm{NO}}[\mathrm{NO}]\left[\mathrm{RO}_{2 i}\right] \\
& -k_{\mathrm{OH}+\mathrm{NO} 2+\mathrm{M}}[\mathrm{M}]\left[\mathrm{NO}_{2}\right][\mathrm{OH}]-\mathrm{P}\left(\mathrm{RONO}_{2}\right)
\end{aligned}
$$

For urban environments like MCMA, including the $\mathrm{NO}_{2}$ lost to $\mathrm{HNO}_{3}$ or organic nitrate $\left(\mathrm{RONO}_{2}\right)$ formation can offset $\sim 10 \%$ of the ozone production and must be included. If $\mathrm{P}\left(\mathrm{O}_{3}\right)$ is calculated only from the measured quantities $\mathrm{HO}_{2}$, $\mathrm{NO}, \mathrm{OH}$, and $\mathrm{NO}_{2}$, then only the first and the third terms

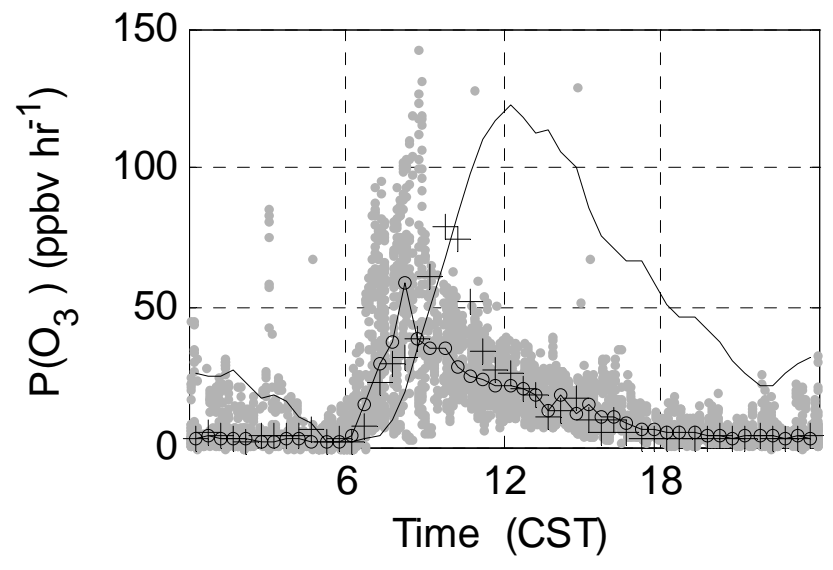

Fig. 13. Diurnal average of instantaneous photochemical ozone production $\left(\mathrm{P}\left(\mathrm{O}_{3}\right)\right.$ ). 30-min median $\mathrm{P}\left(\mathrm{O}_{3}\right)$ from measured $\mathrm{HO}_{2}$ (circles) is compared to 30-min median $\mathrm{P}\left(\mathrm{O}_{3}\right)$ from modeled $\mathrm{HO}_{2}$ (plusses). Median observed ozone (ppbv) is plotted as a solid line to illustrate the lag between the time of maximum $\mathrm{P}\left(\mathrm{O}_{3}\right)$ and the time of maximum $\mathrm{O}_{3}$. Gray dots are individual 30-min median $\mathrm{P}\left(\mathrm{O}_{3}\right)$ from measured $\mathrm{HO}_{2}$.

are retained. This reaction, of course, assumes that all of $\mathrm{HO}_{2}+\mathrm{NO}$ forms $\mathrm{OH}+\mathrm{NO}_{2}$ and that $\mathrm{NO}_{2}$ is photolyzed to produce ozone.

The median $\mathrm{P}\left(\mathrm{O}_{3}\right)$ calculated from measured $\mathrm{HO}_{2}$ peaked at $48 \mathrm{ppbv} \mathrm{h}^{-1}$, while $\mathrm{P}\left(\mathrm{O}_{3}\right)$ calculated from modeled $\mathrm{HO}_{2}$ peaked at $86 \mathrm{ppbvh}^{-1}$ (Fig. 13). Both peaks are broad and achieve maximum values near 10:00 CST. Peak values on some days were greater than $100 \mathrm{ppbv} \mathrm{h}^{-1}$.

The $\mathrm{NO}_{\mathrm{x}}$ peak at morning rush hour is mainly due to fresh $\mathrm{NO}$ emissions (Fig. 8). Beginning at about 05:00 CST, $\mathrm{O}_{3}$ was drawn down by the reaction with $\mathrm{NO}$ to form $\mathrm{NO}_{2}$, but the sum of $\mathrm{NO}_{2}+\mathrm{O}_{3}$ remained relatively constant. As $\mathrm{P}\left(\mathrm{O}_{3}\right)$ began to increase at 06:00 CST, $\mathrm{NO}_{2}+\mathrm{O}_{3}$ began to increase, but more than $90 \%$ of the produced $\mathrm{O}_{3}$ was partitioned into $\mathrm{NO}_{2}$ by reaction with $\mathrm{NO} . \mathrm{O}_{3}$ did not begin to really rise until about 07:30 CST, when NO had fallen to half its peak value and $\mathrm{J}\left(\mathrm{NO}_{2}\right)$ had climbed to $16 \%$ of its peak value. Thus, the sum of $\mathrm{NO}_{2}+\mathrm{O}_{3}$ rose along with $\mathrm{P}\left(\mathrm{O}_{3}\right)$, while the $\mathrm{O}_{3}$ rise appears to have been delayed by about $1.5 \mathrm{~h}$ (Fig. 13).

In New York City, the median mid-morning $\mathrm{P}\left(\mathrm{O}_{3}\right)$ from $\mathrm{HO}_{2}$ was $12 \mathrm{ppbvh}^{-1}$, peaking at 11:00 EDT. On a few days, $\mathrm{P}\left(\mathrm{O}_{3}\right)$ from $\mathrm{HO}_{2}$ reached as high as $50 \mathrm{ppbvh}^{-1}$, but on many days, its peak value was less than $10 \mathrm{ppbvh}^{-1}$. This ozone production rate from $\mathrm{HO}_{2}$ is about five times smaller than that observed in MCMA. The difference in the measured $\mathrm{HO}_{2}$ in MCMA and NYC causes the difference in $\mathrm{P}\left(\mathrm{O}_{3}\right)$.

The cumulative daily surface ozone production from $\mathrm{HO}_{2}$ at the CENICA site was calculated to be 319 ppbv by measurement. To relate cumulative surface ozone production to the observed ozone requires the knowledge of the temporal and spatial variations of $\mathrm{P}\left(\mathrm{O}_{3}\right)$ and $\mathrm{O}_{3}$ throughout the MCMA, both horizontally and vertically. 


\section{Summary and conclusions}

The MCMA 2003 study stretched the envelope of the pollution levels for which a set of atmospheric measurements that included $\mathrm{OH}$ and $\mathrm{HO}_{2}$ have been obtained. We summarize several conclusions from this study.

First, the measurements of $\mathrm{OH} . \mathrm{HO}_{2}$, and $\mathrm{OH}$ reactivity are the first for a megacity in the developing world. This study shows that high-quality measurements are possible in an environment that is more polluted than typical U.S. and European cities.

Second, even in an environment with such high loadings of $\mathrm{NO}_{\mathrm{x}}$ and VOCs, steady-state photochemical models are generally able to simulate the median measured $\mathrm{OH}$ and $\mathrm{HO}_{2}$. Monte Carlo analyses of the VOC speciation types confirms that the sparse speciated VOC measurements in CENICA only slightly degraded the comparison between measurement and model for $\mathrm{OH}$ and $\mathrm{HO}_{2}$. The agreement between the measured and modeled $\mathrm{HO}_{\mathrm{x}}$ is as good as or better than that obtained in other urban environments (George et al., 1999; Martinez et al., 2003; Ren et al., 2003b; Heard et al., 2004).

Second, while the $\mathrm{OH}$ sources and sinks are both substantially increased over those in U.S. cities, the resulting $\mathrm{OH}$ is similar to that observed in U.S. cities. Not so for $\mathrm{HO}_{2}$, which was greater in MCMA than in U.S. cities and is thus directly responsible for the differences seen in the ozone levels between MCMA and U.S. cities.

Third, the $\mathrm{OH}$ reactivity was higher than we have observed in any other outdoor environment, reaching more than $120 \mathrm{~s}^{-1}$ in morning rush hour. Our correction scheme for $\mathrm{HO}_{2}+\mathrm{NO} \rightarrow \mathrm{OH}+\mathrm{NO}_{2}$ allows $\mathrm{OH}$ reactivity measurements to be made in much more polluted environments than before. Because of the poor overlap between speciated $\mathrm{VOC}$ and $\mathrm{OH}$ reactivity measurements at CENICA, the data are insufficient to rule out the possibility that the measured $\mathrm{OH}$ reactivity is as much as $30 \%$ greater than the calculated $\mathrm{OH}$ reactivity, similar to our measurements in Nashville (Kovacs et al., 2003) and to other measurements in Tokyo (Sadanaga et al., 2004).

Fourth, a surprising result is the good agreement as a function of $\mathrm{NO}$ between the $\mathrm{HO}_{2} / \mathrm{OH}$ ratio that is measured and the ratio from a measurement-based steady-state model and a photochemical point model, although the measured ratio is two times greater than the steady-state analysis ratio when NO exceeds 20 ppbv. This agreement is better than we have seen in any other environment where NO exceeded a few ppbv. The difference between these other urban areas and MCMA is not particularly the $\mathrm{NO}_{\mathrm{x}}$ abundance, which is similar to that in New York City, but instead is the large amounts of VOCs that result in high $\mathrm{OH}$ reactivities.

Fifth, the balance between $\mathrm{OH}$ production and loss is generally consistent with the expected $\mathrm{OH}$ steady-state balance. A possible exception is during morning rush hour when $\mathrm{OH}$ production exceeds $\mathrm{OH}$ loss by as much as a factor of two. While the differences are not statistically significant, they do bear watching because they suggest errors in $\mathrm{HO}_{\mathrm{x}}-\mathrm{NO}_{\mathrm{x}}$ photochemistry.

Finally, the combination of high $\mathrm{OH}$ reactivity, abundant sunlight, and $\mathrm{NO}_{\mathrm{x}}$ at morning rush hour jump starts ozone production, which from $\mathrm{HO}_{2}$ alone reached $\sim 50 \mathrm{ppbvh}^{-1}$ by mid-morning. Similar results are found by R. Volkamer (private communication, 2005). Had the meteorological conditions not produced afternoon clouds, occasional rain, and below normal temperatures, midday ozone levels would have been greater.

Acknowledgements. We thank the entire MCMA team for the support they provided us during the MCMA 2003 campaign and for the stimulating discussions at the science workshop. We also thank our colleagues for the use of their data for our model calculations. This work was supported by NSF Atmospheric Chemistry grants (ATM-0209972 and ATM-308748) and the Comisión Ambiental Metropolitana of Mexico. R. Volkamer acknowledges the Henry and Camille Dreyfus Foundation for a Dreyfus postdoctoral fellowship.

Edited by: A. Hofzumahaus

\section{References}

Carslaw, N., Jacoba, P. J., and Pilling, M. J.: Modeling $\mathrm{OH}, \mathrm{HO}_{2}$, and $\mathrm{RO}_{2}$ radicals in the marine boundary layer, 2. Mechanism reduction and uncertainty analysis, J. Geophys. Res., 104, $30257-$ $30273,1999$.

Di Carlo, P, Brune, W. H., Martinez, M., Harder, H., Lesher, R., Ren, X, Thornberry, T., Carroll, M.A., Young, V., Shepson, P. B., Riemer, D., Apel, E., and Campbell, C.: Missing OH reactivity in a forest: Evidence for unknown reactive biogenic VOCs, Science, 304, 722-725, 2004.

Dunlea, E. J., Herndon, S. C., Nelson, D. D., Volkamer, R. M., Lamb, B. K., Allwine, E. J., Grutter, M., Ramos Villegas, C. R., Marquez, C., Blanco, S., Cardenas, B., Kolb, C. E., Molina, L. T., and Molina, M. J.: Technical note: Evaluation of standard ultraviolet absorption ozone monitors in a polluted urban environment, Atmos. Chem. Phys. Discuss., 6, 2241-2279, 2006, http://www.atmos-chem-phys-discuss.net/6/2241/2006/.

Emmerson, K. M., Carslaw, N., Carpenter, L. J., Heard, D. E., Lee, J. D., and Pilling, M. J.: Urban Atmospheric Chemistry during the PUMA Campaign, 1: Comparison of Modelled $\mathrm{OH}$ and $\mathrm{HO}_{2}$ Concentrations with Measurements, J. Atmos. Chem., 52, 143164, 2005.

Faloona, I. C., Tan, D., Lesher, R. L., Hazen, N. L., Frame, C. L., Simpas, J. B., Harder, H., Martinez, M., Di Carlo, P., Ren, X., and Brune, W. H.: A laser induced fluorescence instrument for detecting tropospheric $\mathrm{OH}$ and $\mathrm{HO}_{2}$ : Characteristics and calibration, J. Atmos. Chem., 47, 139-167, 2004.

Fenske, J. D., Hasson, A. S., Paulson, S. E., Kuwata, K. T., Ho, A., and Houk, K. N.: The pressure dependence of the $\mathrm{OH}$ radical yield from ozone-alkene reactions, J. Phys. Chem. A, 104, 78217833, 2000.

George, L. A., Hard, T. M., and O'Brien, R. J.: Measurement of free radicals $\mathrm{OH}$ and $\mathrm{HO}_{2}$ in Los Angeles Smog, J. Geophys. Res., 104, $11643-11655,1999$. 
Hard, T. M., O’Brien, R. J., Chan, C. Y., and Mehrabzadeh, A. A.: Tropospheric free radical determination by FAGE, Environ. Sci. Technol., 18, 768-777, 1984.

Heard, D. E., Carpenter, L. J., Creasey, D. J., Hopkins, J. R., Lee, J. D., Lewis, A. C., Pilling, M. J., Seakins, P. W., Carslaw, N., and Emmerson, K. M.: High levels of the hydroxyl radical in the winter urban troposphere, Geophys. Res. Lett., 31, doi:10.1029/2004GL020544, 2004.

Kleinman, L. I.: Ozone process insights from field experiments part II: Observation-based analysis for ozone production, Atmos. Environ., 34, 2023-2033, 2000.

Kovacs, T. A. and Brune, W. H.: Total $\mathrm{OH}$ loss rate measurement, J. Atmos. Chem., 39, 105-122, 2001.

Kovacs, T. A., Brune, W. H., Harder, H., Martinez, M., Simpas, J. B., Frost, G. J., Williams, E., Jobson, T., Stroud, C., Young, V., Fried, A., and Wert, B.: Direct measurements of urban $\mathrm{OH}$ reactivity during Nashville SOS in summer 1999, J. Environ. Monit., 5, 68-74, doi:10.1039/b204339d, 2003.

Lamb, B., Velasco, E., Allwine, E., Westberg, H., Herndon, S., Knighton, B., Grimsrud, E., Jobson, T., Alexander, M., and Prezeller, P.: Ambient VOC measurements in Mexico City, American Meteorological Society Fifth Conference on Urban Environment, Vancouver, BC, Canada, 23-26 August 2004.

Martinez, M., Harder, H., Kovacs, T. A., Simpas, J. B., Bassis, J., Lesher, R., Brune, W. H., Frost, G. J., Williams, E. J., Stroud, C. A., Jobson, B. T., Roberts, J. M., Hall, S. R., Shetter, R. E., Wert, B., Fried, A., Alicke, B., Stutz, J., Young, V. L., White, A. B., and Zamora, R. J.: $\mathrm{OH}$ and $\mathrm{HO}_{2}$ concentrations, sources, and loss rates during the Southern Oxidants Study in Nashville, Tennessee, summer 1999, J. Geophys. Res., 108, 4617, doi:10.1029/2003JD003551, 2003.

Martinez, M., Harder, H., Brune, W., Di Carlo, P., Williams, E., Hereid, D., Jobson, T., Kuster, W., Roberts, J., Trainer, M., Fehsenfeld, F. C., Hall, S., Shetter, R., Apel, E., Riemer, D., and Geyer, A.: The behavior of the hydroxyl and hydroperoxyl radicals during TexAQS2000, Abstract A12D-0174, AGU Fall Meeting, EOS Transactions, San Francisco, California, 2002.

Molina, L. T. and Molina, M. J. (Ed.): Air Quality in the Mexico Megacity: An integrated assessment, Kluwer Academic Publishers, Boston, 2002.

Mugica, V., Ruiz, M. E., Watson, J., and Chow, J.: Volatile aromatic compounds in Mexico City atmosphere: levels and source apportionment, Atmosfera, 16, 15-27, 2003.

Parrish, D. D., Trainer, M., Young, V., Goldan, P. D., Kuster, W. C., Jobson, B. T., Fehsenfeld, F. C., Lonneman, W. A., Zika, R. D., Farner, C. T., Riemer, D. D., and Rodger, M. O.: Internal consistency test for evaluation of measurements of anthropogenic hydrocarbons in the troposphere, J. Geophys. Res., 103, 22 339$22359,1998$.

Paulson, S. E., Chung, M. Y., and Hasson, A. S.: OH radical formation from the gas-phase reaction of ozone with terminal alkenes and the relationship between structure and mechanism, J. Phys. Chem. A, 103, 8125-8138, 1999.

Ren, X., Harder, H., Martinez, M., Lesher, R. L., Oliger, A., Shirley, T., Adams, J., Simpas, J. B., and Brune, W. H.: $\mathrm{HO}_{\mathrm{x}}$ concentrations and $\mathrm{OH}$ reactivity observations during the PMTACS-NY 2001 campaign in New York City, Atmos. Environ., 37, 36273637, 2003a.
Ren, X., Harder, H., Martinez, M., Lesher, R. L., Oliger, A., Simpas, J. B., Brune, W. H., Schwab, J. J., Demerjian, K. L., He, Y., Zhou, X., and Gao, $\mathrm{H}$.: $\mathrm{OH}$ and $\mathrm{HO}_{2}$ chemistry in the urban atmosphere of New York City, Atmos. Environ., 37, 3639-3651, 2003b.

Ren, X., Harder, H., Martinez, M., Faloona, I., Tan, D., Lesher, R. L., Di Carlo, P., Simpas, J. B., and Brune, W. H.: Interference testing for atmospheric $\mathrm{HO}_{\mathrm{x}}$ measurements by laser-induced fluorescence, J. Atmos. Chem., 47, 169-190, 2004.

Ren, X., Brune, W. H., Cantrell, C. A., Edwards, G. D., Shirley, T., Metcalf, A. R., and Lesher, R. L.: Hydroxyl and peroxy radical chemistry in a rural area of Central Pennsylvania: Observations and model comparisons, J. Atmos. Chem., 52, 231-257, 2005.

Ren, X., Brune, W. H., Oliger, A., Metcalf, A. R., Lesher, R. L., Simpas, J. B., Shirley, T., Schwab, J. J., Bai, C., Li, Y., Demerjian, K. L., and Roychowdhury, U.: $\mathrm{OH}$ and $\mathrm{HO}_{2}$ during the PMTACS-NY Whiteface 2002 Campaign: Observations and Model Comparison, J. Geophys. Res., 111, D10S03, doi:10.1029/2005JD006126, 2006.

Rickard, A. R., Johnson, D., McGill, C. D., and Marston, G.: OH yields in the gas-phase reactions of ozone with alkenes, J. Phys. Chem. A, 103, 7656-7664, 1999.

Sadanaga, Y., Yoshino, A., Kato, S., Yoshioka, A., Watanabe, K., Miyakawa, Y., Hayashi, I., Ichikawa, M., Matsumoto, J., Nishiyama, A., Akiyama, N., Kanaya, Y., and Kajii, Y.: The importance of $\mathrm{NO}_{2}$ and volatile organic compounds in the urban air from the viewpoint of the $\mathrm{OH}$ reactivity, Geophys. Res. Lett., 31, L08102, doi:10.1029/2004GL019661, 2004.

Sander, S. P., Friedl, R. R., Golden, D. M., Kurylo, M. J., Huie, R. E., Orkin, V. L., Moortgat, G. K., Ravishankara, A. R., Kolb, C. E., Molina, M. J., and Finlayson-Pitts, B. J.: Chemical kinetics and photochemical data for use in stratospheric modeling, Evaluation Number 14, JPL Publication 02-25, NASA Jet Propulsion Laboratory, Pasadena, CA, 2003.

Stockwell, W. R., Kirchner, F., and Kuhn, M.: A new mechanism for regional atmospheric chemistry modeling, J. Geophys. Res., 102, 25 847-25 879, 1997.

Velasco, E., Lamb, B., Pressley, S., Allwine, E., Westberg, H., Jobson, T., Alexander, M., Prazeller, P., Molina, L., and Molina, M.: Flux measurements of volatile organic compounds from an urban landscape, Geophys Res. Lett., 32, L20802, doi:10.1029/2005GL023356, 2005.

Volkamer, R., Molina, L. T., Molina, M. J., Shirley, T., and Brune, W. H.: DOAS measurement of glyoxal as an indicator for fast VOC chemistry in urban air, Geophys. Res. Lett., 32, L08806, doi:10.1029/2005GL022616, 2005.

Volz-Thomas, A., Geiss, H., Hofzumahaus, A., and Becker, K.-H.: Introduction to Special Section: Photochemistry Experiment in BERLIOZ, J. Geophys. Res., 108, 8252, doi:10.1029/2001JD002029, 2003.

Volz-Thomas, A., Pätz, H.-W., Houben, N., Konrad, S., Mihelcic, D., Klüpfel, T., and Perner, D.: Inorganic trace gases and peroxy radicals during BERLIOZ at Pabstthum: An investigation of the photostationary state of $\mathrm{NO}_{\mathrm{x}}$ and $\mathrm{O}_{3}$, J. Geophys. Res., 108(D4), 8248, doi:10.1029/2001JD001255, 2003. 